\title{
Long-Term Effects of Aeration and Fire on Invasion of Exotic Grasses in Mixed-Brush Plant Communities
}

\author{
Felix Ayala-A., ${ }^{1}$ J. Alfonso Ortega-S., ${ }^{2}$ Timothy E. Fulbright,${ }^{3}$ G. Allen Rasmussen, ${ }^{4}$ D. Lynn Drawe, ${ }^{5}$ \\ David R. Synatzske, ${ }^{6}$ and Andrea R. Litt ${ }^{7}$
}

Authors are ${ }^{1} \mathrm{PhD}$ Candidate, ${ }^{2}$ Professor and Research Scientist, and ${ }^{3}$ Regents Professor and Endowed Meadows Professor, Caesar Kleberg Wildife Research Institute, Texas A ${ }^{\prime} M$ University-Kingsville, Kingsville, TX 78363, USA; ${ }^{4}$ Dean, Professor, and Research Scientist, Dick \& Mary Lewis Kleberg College of Agriculture, Natural Resources, and Human Sciences, Texas A\&M University-Kingsville, Kingsville, TX 78363, USA; ${ }^{5}$ Former Director, Rob and Bessie Welder Wildlife Foundation, Sinton, TX 78387, USA; ${ }^{6}$ Manager, Chaparral Wildlife Management Area, Texas Parks and Wildlife Department, Artesia Wells, TX 78001, USA; and 'Assistant Professor, Department of Ecology, Montana State University, Bozeman, MT 59717, USA.

\begin{abstract}
Invasion of exotic grasses into grasslands dominated by native plants changes fire cycles and reduces biodiversity. Brush management practices that create soil disturbance, such as aeration, may potentially result in invasion of exotic grasses and replacement of native vegetation. We tested the hypothesis that a long-term effect of aeration and prescribed burning is an increase in exotic grasses. The study was conducted at the Chaparral Wildlife Management Area in the western south Texas plains where four treatments were evaluated: aeration, warm-season burn, aeration followed by a warm-season burn, and no treatment (control). The experimental design was a randomized complete block with four replicates. We estimated percentage canopy cover of exotic grasses, native grasses, forbs, litter, bare ground, and woody and succulent plants in 2007. There was a multivariate main effect among treatments for the dependent variables absolute canopy cover of exotic grasses, native grasses, forbs, litter, and bare ground (Wilks's Lambda $\mathrm{F}_{15,179.84}=2.78, P=0.001$ ). Variables that contributed to the significant overall effect included litter $\left(\mathrm{F}_{3,69}=4.32, P=0.008\right)$ and native grasses $\left(\mathrm{F}_{3,69}=6.11, P=0.001\right)$. The multivariate main effect of treatment was significant (Wilks's Lambda $\mathrm{F}_{9,180.25}=2.04, P=0.038$ ) for the relative canopy cover of herbaceous species. Relative cover of exotic grasses was $31 \%$ higher $(P=0.024)$ in control than in the prescribed burn treatment. Native grasses relative cover was $30 \%$ higher $(P=0.003)$ in prescribed burn than in the control treatment. We did not detect differences among treatments in the percentage of total woody and succulent plants canopy cover $(P=0.083)$. Under the environmental conditions at the time of the study, aeration and/or prescribed burning do not increase exotic grasses.
\end{abstract}

\section{Resumen}

La invasión de zacates exóticos en pastizales dominados por plantas nativas modifica los ciclos del fuego y reducen la biodiversidad. Las prácticas de manejo de arbustivas que crean disturbios al suelo, tales como aeración, potencialmente pudieran causar la invasión de zacates exóticos y reemplazar la vegetación nativa. Se examinó la hipótesis de que el efecto a largo plazo de la aireación y quema prescrita es un incremento de zacates exóticos. El estudio se realizó en el Chaparral Wildlife Management Area en las planicies del oeste del sur de Texas, donde se evaluaron cuatro tratamientos: aireación, quema de verano, aireación seguida de una quema de verano y sin tratamiento (control). El diseño experimental fue de bloques completamente al azar con cuatro repeticiones. Se estimaron porcentajes de cobertura aérea de zacates exóticos, zacates nativos, hierbas, mantillo, suelo desnudo y plantas arbustivas y suculentas en 2007. Se encontró un efecto multivariado para las variables dependientes de cobertura aérea absoluta de zacates exóticos, zacates nativos, hierbas, mantillo y suelo desnudo entre tratamientos (Wilks's Lambda $\mathrm{F}_{15}$, $179.84=2.78, P=0.001)$. Las variables que contribuyeron al efecto significativo fueron mantillo $\left(\mathrm{F}_{3,69}=4.32, P=0.008\right)$ y zacates nativos $\left(\mathrm{F}_{3,69}=6.11, P=0.001\right)$. El efecto multivariado del tratamiento fue significativo (Wilks's Lambda $\mathrm{F}_{9}$, $180.25=2.04, P=0.038)$ para la cobertura aérea relativa de las especies herbáceas. La cobertura relativa de los zacates exóticos fue $31 \%$ mayor $(P=0.024)$ en el control que en el tratamiento que quema prescrita. La cobertura de los zacates nativos fue $30 \%$ mayor $(P=0.003)$ en quema prescrita que en el tratamiento control. No se detectaron diferencias entre tratamientos en el porcentaje de cobertura aérea total de plantas arbustivas y suculentas $(P=0.083)$. Bajo las condiciones ambientales al momento del estudio, la aireación y/o quema prescrita no incrementaron los zacates exóticos.

Key Words: cover, litter, native vegetation, prescribed burn

Research was funded by the United States Department of Agriculture-Natural Resources Conservation Service, Texas Parks and Wildlife Department, and the Caesar Kleberg Wildlife Research Institute.

At the time of the research, Ayala-A. was a doctoral candidate, Caesar Kleberg Wildlife Research Institute, Texas A\&M University-Kingsville, Kingsville, TX 78363, USA.

Correspondence: J. Alfonso Ortega-S., Caesar Kleberg Wildlife Research Institute, Texas A\&M University-Kingsville, 700 University Blvd, MSC 218, Kingsville, TX 78363, USA. Email: poncho.ortega@tamuk.edu

Manuscript received 26 March 2011; manuscript accepted 3 December 2011.

\section{INTRODUCTION}

Mechanical and pyric methods of brush management have been used to reduce woody cover and to promote herbaceous vegetation production (Bozzo et al. 1992; Drawe et al. 1999). Brush management is applied on rangelands for various purposes, including increasing production of forage for livestock and maintaining high-quality habitat for wildlife (Guthery 1986; Adams et al. 1992; Reynolds et al. 1992). Exotic grasses have 
been purposely introduced throughout the southwestern United States and northern Mexico to meet the goals of forage production for livestock or to prevent soil erosion following brush management (Martin-R. et al. 1995; Martín-Rivera et al. 2001) when native species are not able to meet the desired function. A common brush management practice is aeration, consisting of cutting the stems and trunks of woody plants and creating pits in the soil surface, which reduces soil compaction and promotes retention and infiltration of precipitation (Fulbright and Ortega-S. 2006). The implement results in top removal of woody vegetation while leaving herbaceous vegetation intact.

Exotic grasses often expand well beyond sites where they have been planted and replace native vegetation (Gonzalez and Dodd 1979; Angell and McClaran 2001). In addition to loss of native plant species diversity, establishment of dense stands of exotic grass species reduces habitat quality for grassland bird species and insects (Bock et al. 1986; Barnes et al. 1995; Peterson 2001; Flanders et al. 2006; Hickman et al. 2006). Exotic grass establishment also may result in more intense wildfires because of increased fuel loads and continuity compared to stands of native grasses (D'Antonio and Vitousek 1992). Modifications in frequency, intensity, and type of disturbance are usually implicated in the invasion of plant communities by exotic species (Hobbs and Huenneke 1992; Burke and Grime 1996; Smith and Knapp 1999).

Long-term effects of brush management on composition and diversity of native and exotic herbaceous vegetation have received little attention by researchers (Nolte et al. 1994). Disturbance by mechanical or pyric brush management may facilitate encroachment by exotic grasses (Milberg and Lamont 1995), and the potential for invasion of exotic grasses and replacement of native plants following brush management needs to be understood because native vegetation is an important component of wildlife habitat (Fulbright and Ortega-S. 2006; Fulbright et al. 2008). Our objective was to determine if disturbances by aeration and prescribed burning result in increased invasion of exotic grasses and reduce native herbaceous vegetation in the long term in the mixed-brush plant communities of western south Texas. We hypothesized that disturbance by aeration and prescribed burning will increase exotic grasses compared to nontreated areas.

\section{METHODS}

The study was conducted on the 6150 ha Chaparral Wildlife Management Area (CWMA) (lat $28^{\circ} 18^{\prime} \mathrm{N}$, long $99^{\circ} 24^{\prime} \mathrm{W}$ ) in the western south Texas plains. The CWMA has been operated by the Wildlife Division of the Texas Parks and Wildlife Department (TPWD) since 1969 and serves as a research and demonstration facility representative of the South Texas Plains ecological region. Precipitation pattern is bimodal with peaks in late spring and early autumn. The 19-yr average annual precipitation is $560 \mathrm{~mm}$ (1989-2007, TPWD unpublished data), with a high interannual variability (Fig. 1). The soils in the research site are Duval fine sandy loam on gently undulating slopes, Dilley fine sandy loam on gently undulating slopes, and Duval loamy fine sand on $0-5 \%$ slopes. The Duval series are fine-loamy, siliceous, hyperthermic Aridic Haplustalfs, and the
Dilley series are loamy, mixed, hyperthermic, shallow Ustalfic Haplargids (USDA-NRCS 2010).

Plant communities belong to the honey mesquite (Prosopis glandulosa Torr.)-spiny hackberry (Celtis palida Torr.) association (McLendon 1991). Within this association were 2 primary communities: honey mesquite-lime pricklyash [Zanthoxylum fagara (L.) Sarg.]/spiny hackberry/hog plum (Colubrina texensis T. \& G.) community, with hog plum the subdominant. Prominent herbaceous species include hooded windmillgrass (Chloris cucullata Bisch.), hairy grama (Bouteloua hirsuta Lag.), partridge pea [Chamaecrista fasciculata (Michx.) Greene], croton (Croton spp.), and two introduced perennials: buffelgrass [Pennisetum ciliare (L.) Link] and Lehmann lovegrass (Eragrostis lehmanniana Nees) (Ruthven and Krakauer 2004). Common names and scientific nomenclature of plants follow the style of Hatch and Pluhar (1993), Gould (1978), and Everitt et al. (1999, 2002). Domestic livestock have grazed the study area since the 18th century (Lehmann 1969), dominated by sheep from 1750 to 1870 and then cattle since 1870 . Grazing strategies have varied from continuous grazing to various rotational grazing systems (Ruthven et al. 2000). When the TPWD began operating this area in 1969, a rotational grazing system was implemented until 1984. From 1990 to 2005 , the study area was grazed under a high-intensity, low-frequency grazing system. There was no livestock grazing from 1984 to 1990 or after 2005 as a result of drought. Total deer density at the CWMA during 1999-2007 ranged from 7.1 to $13.3 \mathrm{ha} \cdot$ deer $^{-1}$; adult deer density ranged from 7.4 to 20.7 ha $\cdot$ deer $^{-1}$ (TPWD unpublished data).

Detailed information on mechanical disturbances conducted before 1969 is unavailable; however, some study plots were disturbed before 1952 by root plowing and/or chaining, and others chained between 1952 and 1969. At least half of the plots we used were not mechanically disturbed before this study; therefore previous disturbances were not taken into account. There is no record of exotic grasses being seeded in the study area; therefore, exotic grasses present in the area were assumed to have invaded from elsewhere. Information regarding historical disturbances was obtained from aerial photographs from 1952 and 1969, and personal communication from David R. Synatzske, Texas Parks and Wildlife, November 2009.

\section{Experimental Design and Statistical Analysis}

Treatments were established using a randomized complete block design with four replications, with blocking based on edaphic and topographic variation. We examined four treatments: aeration, prescribed burning, aeration plus prescribed burning, and control (no record of previous fire or mechanical treatment). Each treatment was considered to be independent from one another. Aeration was performed in 1999 or 2000 using one pass of a double/tandem $4.4 \times 0.8 \mathrm{~m}$ drum aerator (Lawson Manufacturing, Kissimmee, FL). Rows of blades attached perpendicular to the axis of the drum cut the stems and trunks of woody plants and create pits in the soil surface (Fulbright and Ortega-S. 2006). Prescribed burns were conducted during summer or early autumn 2005. Conditions recorded on the CWMA were similar among fires; maximum daily temperatures were between $26^{\circ} \mathrm{C}$ and $37^{\circ} \mathrm{C}$, relative humidity ranged from $30 \%$ to $55 \%$, and sustained wind speeds 


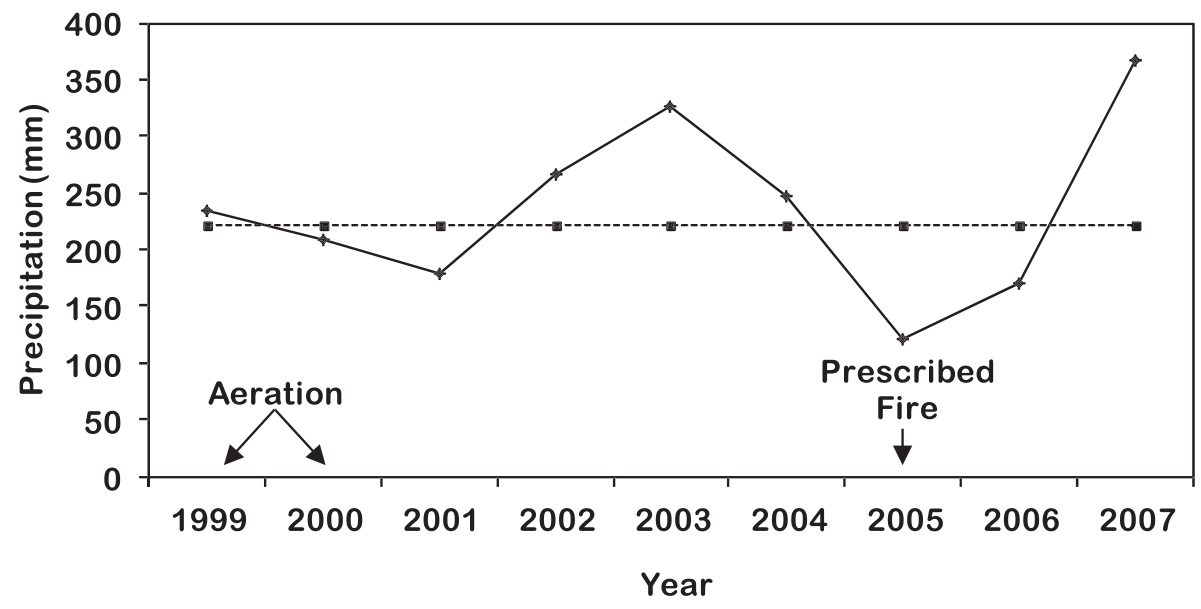

$\longrightarrow$ Precipitation ------ Annual Mean

Figure 1. Annual (solid line) and 19-yr average (dotted line) precipitation (mm) from 1999 to 2007, Chaparral Wildlife Management Area, Artesia Wells, Texas.

averaged 16-20 kph. Information on fire intensity was not available.

Eight patches ranging in size from 1.8 ha to 6.53 ha were aerated in 1999 or 2000 on the CWMA. Three of the aerated patches were completely burned during 2005, and one was partially burned $(35 \%)$. Four patches ranging in size from 12.4 ha to 51.3 ha were burned during 2005. From these, we selected four aerated patches, four aerated and burned patches, four burned patches with no mechanical treatment, and four adjacent untreated sites to obtain four groups of patches. Each of the four treatments within a group was close to the others, and each group was considered to be a block in statistical analyses. In each patch, a 30-m north-south transect was systematically established for vegetation sampling within each patch. Distance between transects within a treatment varied from $100 \mathrm{~m}$ to $800 \mathrm{~m}$ within each block (group of patches), and the distance between blocks (groups of patches) ranged from $2200 \mathrm{~m}$ to $8500 \mathrm{~m}$. On each transect, we visually estimated percent canopy cover of bare ground, litter, and herbaceous plants during autumn 2007 using $20 \times 50 \mathrm{~cm}$ quadrats placed every $5 \mathrm{~m}$ along the transect, for a total of five quadrats per transect (Daubenmire 1959). Sampling size adequacy was determined using the species area curve procedure for native grass composition (Cain 1938). We measured percent canopy cover of woody and succulent plants during autumn 2007 based on the line-intercept method along each transect (Canfield 1941). Sampling method was based on previous vegetation surveys by CWMA personnel.

Response variables included percentage absolute canopy cover of exotic grasses (buffelgrass and Lehmann lovegrass), native grasses (Table 1), forbs (Table 1), litter, bare ground, and woody and succulent plants. We converted percentage absolute canopy cover of herbaceous species to relative canopy cover by dividing absolute canopy cover for each herbaceous variable by the total canopy cover of all herbaceous variables combined. We transformed cover variables to meet assumptions of homogeneity of variance. We included a blocking factor to account for inherent variation across the land- scape and incorporated a Kenward-Roger correction for test statistics and degrees of freedom to reduce bias (Littell et al. 2006). We examined collective changes in cover variables by treatment using a multivariate analysis of variance (MANOVA). Variables with an effect were analyzed with analysis of variance (ANOVA) and Tukey's multiple range test (SAS Institute 2008).

\section{RESULTS}

\section{Absolute Canopy Cover}

Absolute canopy cover of exotic grasses, native grasses, forbs, litter, and bare ground differed among treatments (Wilks's Lambda $\left.\mathrm{F}_{15,179.84}=2.78, P=0.001\right)$, specifically resulting from variation in litter $\left(F_{3,69}=4.32, P=0.008\right)$ and native grasses $\left(\mathrm{F}_{3,69}=6.11, P=0.001\right)$ among treatments. Cover of litter in the control was $>25 \%$ higher $(P=0.008)$ than in the aeration, prescribed burning, aeration plus prescribed burning treatments. Canopy cover of native grasses was higher $(P=0.002)$ in the aeration plus prescribed burning $(63 \pm 15 \%) \quad($ mean $\pm S E)$ and prescribed burning treatment $(60 \pm 6 \%)$ compared to the control $(20 \pm 5 \%)$, and native grass canopy cover in the aeration treatment was similar to the aeration plus prescribed burning, prescribed burning treatments and to the control, with $45 \pm 9 \%$ (Table 2 ).

\section{Relative Canopy Cover of Herbaceous Vegetation}

Relative canopy cover of exotic grasses, native grasses, and forbs differed among treatments (Wilks's Lambda $\mathrm{F}_{9,180.25}=2.04$, $P=0.038)$, specifically resulting from differences in exotic $\left(\mathrm{F}_{3}\right.$, $\left.{ }_{76}=3.32, P=0.024\right)$ and native grasses $\left(\mathrm{F}_{3,76}=4.95, P=0.003\right)$ among treatments. Canopy cover of exotic grasses was $31 \%$ greater $(P=0.024)$ in the control $(42 \pm 9 \%)$ than the prescribed burning treatment $(11 \pm 3 \%)$. Canopy cover of native grasses was $30 \%$ higher $(P=0.003)$ in the prescribed burning treatment $(60 \pm 5 \%)$ compared to the control $(30 \pm 6 \%)$ (Table 2$)$. 
Table 1. Common and scientific names of the natives grasses and forbs found on aeration, prescribed burning, aeration plus prescribed burning, and control sites in autumn 2007, Chaparral Wildlife Management Area, Artesia Wells, Texas.

\begin{tabular}{|c|c|}
\hline Common name & Scientific name \\
\hline \multicolumn{2}{|l|}{ Native grasses } \\
\hline Common witchgrass & Panicum capillare L. \\
\hline Fall witchgrass & Digitaria cognata (Schult.) Pilger \\
\hline Fringed signalgrass & Brachiaria ciliatissima (Buckl.) Chase \\
\hline Grassbur & Cenchrus incertus M. A. Curtis \\
\hline Hairy grama & Bouteloua hirsuta Lag. \\
\hline Hooded windmillgrass & Chloris cucullata Bisch. \\
\hline Lovegrass tridens & Tridens eragrostoides (Vasey \& Scribn.) Nash. \\
\hline Plains bristlegrass & Setaria leucopila (Scribn. \& Merr.) Schum. \\
\hline Plains lovegrass & Eragrostis intermedia Hitchc. \\
\hline Purple threeawn & Aristida purpurea Nutt. \\
\hline Red lovegrass & Eragrostis secundiflora Presl. \\
\hline Sedge & Carex spp. \\
\hline Slim tridens & Tridens muticus (Torr.) Nash \\
\hline Thin paspalum & Paspalum setaceum Michx. \\
\hline Tumble lovegrass & Eragrostis sessilispica Buckl. \\
\hline Windmillgrass & Chloris verticillata Nutt. \\
\hline \multicolumn{2}{|l|}{ Forbs } \\
\hline Awnless bush sunflower & Simsia calva (Engelm. \& Gray) Gray \\
\hline Beebalm & Monarda spp. \\
\hline Blackfoot daisy & Melampodium cinereum DC. \\
\hline Bladderpod & Lesquerella spp. \\
\hline Bristleleaf dogweed & Thymophylla tenuiloba (DC.) Small \\
\hline Broomweed & Gutierrezia spp. \\
\hline Coreopsis & Coreopsis spp. \\
\hline Croton & Croton spp. \\
\hline Dayflower & Commelina spp. \\
\hline Deer pea vetch & Vicia Iudoviciana Nutt. \\
\hline Dodder & Cuscuta spp. \\
\hline Globemallow & Sphaeralcea spp. \\
\hline Gray goldaster & Heterotheca canescens (DC.) Shinners \\
\hline Ground cherry & Physalis cinerascens (Dun.) A. S. Hitchc. \\
\hline Indian blanket & Gaillardia pulchella Foug. \\
\hline Lazy daisy & Aphanostephus ramosissimus DC. \\
\hline Morning glory & Ipomoea trichocarpa Ell. \\
\hline Palafoxia & Palafoxia texana DC. \\
\hline Partridge pea & Chamaecrista fasciculata (Michx.) Greene \\
\hline Pepperweed & Lepidium spp. \\
\hline Plantain & Plantago spp. \\
\hline Powderpuff & Mimosa strigillosa T. \& G. \\
\hline Ragweed & Ambrosia cumanensis Kunth in H.B.K. \\
\hline Sida & Sida spp. \\
\hline Slender vervain & Verbena officinale L. \\
\hline Texas virgin's bower & Clematis drummondii T. \& G. \\
\hline Texas sleepy daisy & Xanthisma texanum DC. \\
\hline Turkey tangle & Phyla nodiflora (L.) Greene \\
\hline $\begin{array}{l}\text { Upright prairie coneflower } \\
\text { Wood sorrel }\end{array}$ & $\begin{array}{l}\text { Ratibida columnifera (Nutt.) Woot. \& Standl. } \\
\text { Oxalis spp. }\end{array}$ \\
\hline
\end{tabular}

\section{Response of Woody and Succulent Vegetation}

Total canopy cover of woody and succulent plants was relatively similar $(P=0.083)$ in the aeration treatments $(28.61 \pm 5.12 \%)$, prescribed burning $(46.38 \pm 12.38 \%)$, aeration plus prescribed burning $(23.97 \pm 2.63 \%)$, and the control $(51.46 \pm 8.1 \%)$. Canopy cover of the dominant species of woody and succulent plants was also similar $(P>0.05)$ among treatments (Table 3$)$.

\section{DISCUSSION}

Although disturbance commonly is a driving mechanism in exotic grass invasion (D'Antonio and Meyerson 2002), in our study aeration and/or prescribed burning did not increase exotic grasses when looking at the herbaceous canopy cover as a community. After the 7-8-yr period from the initial disturbance for this study, the effect of aeration by itself on native grasses disappeared when compared to the nontreated area. On the other hand, prescribed fire and the combination of disturbances by aeration and fire resulted in a higher absolute cover of native grasses. One of the reasons for the increase in native grass absolute cover could be the result from the removal of old growth and litter by the fire, promoting an increase in new growth compared to untreated areas. Another explanation could be the directional vegetation change that occurs after a disturbance by aeration or fire, since these disturbances are not severe enough to shift the community to a new configuration or stable state; instead there is a dynamic change in vegetation composition. Similar results have been reported in a grasslandsavanna system in Michigan where Suding and Gross (2006) found that burning did not yield consistent effects on species richness. They reported that the removal of litter after burning and the increment of available resources could enhance propagation of either native or exotic species.

Under the conditions in which this research was conducted, disturbances by aeration, prescribed fire, and grazing did not exacerbate absolute cover of exotic grasses; however, a possibility that could occur is the long-term lag effects in response of exotic species to disturbances by aeration and fire (Johnson and Fulbright 2008). Meaning, that exotic plants may be present in relatively low amounts for decades before a rapid expansion in dominance and population growth may occur

Table 2. Percentage (mean $\pm \mathrm{SE}$ ) of absolute and relative canopy cover of important variables on aeration, prescribed burning, aeration plus prescribed burning, and control ( $n=4$ for each treatment) sites in autumn 2007, Chaparral Wildlife Management Area, Artesia Wells, Texas.

\begin{tabular}{lcccc}
\hline \multicolumn{1}{c}{ Class } & Aeration & Prescribed & $\begin{array}{c}\text { Aeration plus } \\
\text { brescribed } \\
\text { burning }\end{array}$ & Control \\
\hline Absolute canopy cover & & & & \\
$\quad$ Litter & $26 \pm 7 \mathrm{~b}^{2}$ & $21 \pm 5 \mathrm{~b}$ & $23 \pm 4 \mathrm{~b}$ & $51 \pm 9 \mathrm{a}$ \\
$\quad$ Native grasses & $45 \pm 9 \mathrm{ab}$ & $60 \pm 6 \mathrm{a}$ & $63 \pm 15 \mathrm{a}$ & $20 \pm 5 \mathrm{~b}$ \\
Relative canopy cover & & & & \\
$\quad$ Exotic grasses & $31 \pm 7 \mathrm{ab}$ & $11 \pm 3 \mathrm{~b}$ & $28 \pm 6 \mathrm{ab}$ & $42 \pm 9 \mathrm{a}$ \\
$\quad$ Native grasses & $41 \pm 6 \mathrm{ab}$ & $60 \pm 5 \mathrm{a}$ & $42 \pm 6 \mathrm{ab}$ & $30 \pm 6 \mathrm{~b}$ \\
\hline
\end{tabular}

${ }^{1}$ Different letters within rows indicate differences at $P \leq 0.05$.

${ }^{2}$ Reporting raw means, statistical differences based on transformed data. 
Table 3. Percentage (mean $\pm \mathrm{SE}$ ) of canopy cover of dominant (frequency $>25 \%$ ) woody and succulent species on aeration, prescribed burning, aeration plus prescribed burning, and control ( $n=4$ for each treatment) sites in autumn 2007, Chaparral Wildlife Management Area, Artesia Wells, Texas. Statistically significant differences $(P \leq 0.05)$ were not detected among treatments.

\begin{tabular}{|c|c|c|c|c|}
\hline Class/species & Aeration & $\begin{array}{c}\text { Prescribed } \\
\text { burning }\end{array}$ & $\begin{array}{l}\text { Aeration plus } \\
\text { prescribed } \\
\text { burning }\end{array}$ & Control \\
\hline \multicolumn{5}{|l|}{ Woody } \\
\hline $\begin{array}{l}\text { Mesquite (Prosopis } \\
\text { glandulosa) }\end{array}$ & $8.8 \pm 4.4$ & $21.8 \pm 13.5$ & $1.9 \pm 1.1$ & $12.8 \pm 9.4$ \\
\hline $\begin{array}{l}\text { Brasil (Condalia } \\
\quad \text { hookerı) }\end{array}$ & $0 \pm 0$ & $3.8 \pm 2.8$ & $0.8 \pm 0.8$ & $0.6 \pm 0.6$ \\
\hline $\begin{array}{r}\text { Spiny hackberry } \\
\text { (Celtis palida) }\end{array}$ & $1.1 \pm 0.9$ & $3.3 \pm 3.3$ & $0.2 \pm 0.2$ & $0 \pm 0$ \\
\hline $\begin{array}{l}\text { Hog plum (Colubrina } \\
\text { texensis) }\end{array}$ & $8.3 \pm 7.8$ & $3.5 \pm 3.5$ & $5.9 \pm 3.4$ & $2.7 \pm 2.7$ \\
\hline $\begin{array}{l}\text { Texas persimmon } \\
\text { (Diospyros texana) }\end{array}$ & $1.2 \pm 1.2$ & $2.7 \pm 2.1$ & $1.7 \pm 1.7$ & $10.3 \pm 8.9$ \\
\hline $\begin{array}{l}\text { Twisted acacia (Acacia } \\
\text { schaffnerı) }\end{array}$ & $5.6 \pm 2.6$ & $2.3 \pm 2.3$ & $3.0 \pm 1.8$ & $1.0 \pm 1.0$ \\
\hline $\begin{array}{l}\text { Whitebrush (Aloysia } \\
\text { gratissima) }\end{array}$ & $0.6 \pm 0.6$ & $3.2 \pm 3.2$ & $5.3 \pm 5.3$ & $1.6 \pm 0.6$ \\
\hline Succulents & & & & \\
\hline $\begin{array}{l}\text { Prickly pear (Opuntia } \\
\text { engelmannii) }\end{array}$ & $0.04 \pm 0.04$ & $1.0 \pm 1.0$ & $0 \pm 0$ & $0.3 \pm 0.2$ \\
\hline
\end{tabular}

(Hobbs and Humphries 1995; Crooks and Soule 1999; Crooks 2005). An explanation for this effect could be the lack of precipitation and drought effect after each disturbance by aeration and prescribed fire. In this region, precipitation has high interannual variability, with prolonged droughts and extreme rainfall periods (Norwine and Kuruvilla 2007), and the response of exotic grasses following a disturbance depends on moisture availability; the response may be favorable if rainfall follows the disturbance (Gonzalez and Dodd 1979; Scifres and Hamilton 1993; Martin-R. et al. 1995; Ibarra-F. et al. 1996; Martin-R. et al. 1999). In this study, 1 yr following the aeration treatments in 1999 or 2000, the annual precipitation was below the 19-yr average (Fig. 1). When the prescribed burn was conducted in 2005, the CWMA had the lowest precipitation since the aeration treatments were established, and the following year was also below the 19-yr precipitation average. Drought, therefore, may have inhibited or postponed establishment of exotic grasses in the aeration and/or prescribed burning treatments as a result of low precipitation during two years following the prescribed burn (Fig. 1). Climatic fluctuations, as the one described in this study, have been reported to have a short-term impact on the directional vegetation change in the semiarid rangelands (Fuhlendorf et al. 2001). It has also been documented that precipitation has played an important role in the establishment or propagation of either native or exotic species after a disturbance by fire or mechanical means in other studies in southern Texas, since canopy cover of herbaceous vegetation following brush management increased considerably if precipitation was average or greater (Scifres and Polk 1974; Bozzo et al. 1992).

In our study the effect of the disturbance by aeration depended on whether or not a prescribed fire was applied; prescribed fire without aeration resulted in reduced relative cover of exotic grasses and more native grasses $2 \mathrm{yr}$ after the fire. Disturbances by aeration and fire are not the only factor influencing our results. Soil properties and moisture conditions before, during, and after disturbances by fire and aeration also play an important role in the establishment or propagation of either native or exotic species. It has also been proposed that burning patches across the landscape could be a tool to increase heterogeneity in rangelands (Fuhlendorf and Engle 2001), and that by attracting large herbivores by the forage regrowth on recently burned patches would increase the grazing pressure on the burned patches compared to unburned areas (Vermeire et al. 2004); even so in this study, livestock grazing was not present after the prescribed fire, and grazing by wildlife species could have caused an impact in the burned patches. A hypothesis regarding the reduction in relative cover of exotic grasses in disturbed areas is their capacity to quickly recover after a fire, responding with an increase in resprouts, biomass production, and nutritive value (Hamilton and Scifres 1982; Everitt and Mayeux 1983; Mayeux and Hamilton 1983; Scifres and Hamilton 1993; Ibarra-F. et al. 1996), attracting wildlife species. Immature foliage of buffelgrass, for example, may comprise a major portion of white-tailed deer (Odocoileus virginianus) diets (Meyer et al. 1984). Therefore, the increased herbivory by wildlife species on exotic plant regrowth in combination with the lack of moisture availability after aeration and/or fire may have reduced exotic grasses in disturbed areas. Exotic plants on undisturbed areas were well established and may have had low palatability; therefore, preference for these areas by wildlife species may have been limited. Other research have reported results similar to ours: Simmons (2005) in a study in central Texas reported that a growing season fire reduced canopy cover of the exotic grass King Ranch bluestem [Bothriochloa ischaemum (L.) Keng] and increased cover of many native grasses and forbs; however, it was a short-term study, and the environmental conditions under which the study was conducted were not described. Similarly, long-term annually burned grasslands in Kansas resulted in reduced exotic plant species richness and canopy cover when compared to unburned sites (Smith and Knapp 1999, 2001). Our results contradict several other studies that detected increases in exotic perennial grasses following prescribed fires (Low 1997; Grace et al. 2001). However, burning exotic grasses during different phenological stages may have different effects on post-fire growth; in our study, the warm season prescribed burn conducted during the peak growth stage of the exotic grasses in this region might have reduced the biomass production afterward (Cox et al. 1990; Martin-R. et al. 1999).

\section{IMPLICATIONS}

Our results contradicted previous studies wherein prescribed fire promoted the increase of several exotic grasses (Milberg and Lamont 1995; Grace et al. 2001). Additional research is 
needed to determine why disturbance by fire reduced relative cover of exotic grasses and increased absolute and relative cover of native grasses in our study. Aeration as an initial disturbance to reduce woody canopy cover and to promote herbaceous vegetation, followed by prescribed burning after a few years as a follow-up to suppress woody species may result in greater herbaceous species richness.

A major concern is that disturbance associated with brush management may facilitate ingress of exotic grasses; however, our results demonstrate that this is not always the case. Ecosystems are highly complex, and additional research is needed to develop greater understanding of how aeration and burning influence the processes and mechanism underlying the dynamics of exotic grass invasion and native plant communities.

\section{LITERATURE CITED}

Adams, C. E., J. K. Thomas, and C. W. Ramsey. 1992. A synopsis of Texas hunting leases. Wildlife Society Bulletin 20:188-197.

AngelL, D. L., and M. P. McClaRan. 2001. Long-term influences of livestock management and a non-native grass on grass dynamics in the desert grassland. Journal of Arid Environments 49:507-520.

Barnes, T. G., L. A. Madison, J. D. Sole, and M. J. Lacki. 1995. An assessment of habitat quality for northern bobwhite in tall fescue-dominated fields. Wildlife Society Bulletin 23:231-237.

Bock, C. E., J. H. Bock, K. L. Jepson, and J. C. Ortega. 1986. Ecological effects of planting African lovegrasses in Arizona. National Geographic Research 2:456-463.

Bozzo, J. A., S. L. Beasom, and T. E. Fulbright. 1992. Vegetation responses to 2 brush management practices in south Texas. Journal of Range Management 45:170-175.

Burke, M., and J. P. Grime. 1996. An experimental study of plant community invasibility. Ecology 77:776-790.

Cain, S. A. 1938. The species-area curve. American Midland Naturalist 19:573-581.

Canfield, R. H. 1941. Application of the line interception method in sampling range vegetation. Journal of Forestry 39:388-394.

Cox, J. R., F. A. Ibarra-F., and M. H. Martin-R. 1990. Fire effects on grasses in semiarid deserts. In: J. S. Krammer [ED.]. Effects of fire management of southwestern natural resources. Fort Collins, CO, USA: US Department of Agriculture, Forest Service, Rocky Mountain Forest and Range Experiment Station. Gen. Tech. Rep. RM-191. p. 43-49.

Crooks, J. A. 2005. Lag times and exotic species: the ecology and management of biological invasions in slow-motion. Ecoscience 12:316-329.

Crooks, J. A., And M. E. Soule. 1999. Lag times in population explosions of invasive species: causes and implications. In: 0. T. Sandlund, P. J. Schei, and A. Viken [EDS.]. Invasive species and biodiversity management. Dordrecht, The Netherlands: Kluwer Academic Publishers. p. 103-125.

D'Antonio, C., and L. A. Meyerson. 2002. Exotic plant species as problems and solutions in ecological restoration: a synthesis. Restoration Ecology 10:703-713.

D’Antonio, C. M., And P. M. Vitousek. 1992. Biological invasions by exotic grasses, the grass/fire cycle, and global change. Annual Review of Ecology and Systematics 23:63-87.

Daubenmire, R. 1959. A canopy-coverage method of vegetational analysis. Northwest Science 33:43-64.

Drawe, D. L., J. A. Ortega-S., and T. E. Fulbright. 1999. Habitat management of white-tailed deer. Proceedings of the wildlife conservation and management workshop; 18-20 August 1999; Saltillo, Coahuila, Mexico: Universidad Autonoma Agraria Antonio Narro. p. 259-268.

Everitt, J. H., D. L. Drawe, and R. I. Lonard. 1999. Field guide to the broad-leaved herbaceous plants of south Texas used by livestock and wildlife. Lubbock, TX, USA: Texas Tech University Press. 249 p.
Everitt, J. H., D. L. Drawe, and R. I. Lonard. 2002. Trees, shrubs, and cacti of south Texas. Lubbock, TX, USA: Texas Tech University Press. 249 p.

EveritT, J. H., AND H. S. Mayeux. 1983. Nutritive contents of two grasses and one browse species following rangeland burning in south Texas. Southwestern Naturalist 28:242-244.

Flanders, A. A., W. P. Kuvlesky, JR., D. C. Ruthven, III, R. E. Zaiglin, R. L. Bingham, T. E. Fulbright, F. Hernández, and L. A. Brennan. 2006. Effects of invasive exotic grasses on south Texas rangeland breeding birds. The Auk 123:171-182.

Fuhlendorf, S. D., D. D. Briske, and F. E. Smeins. 2001. Herbaceous vegetation change in variable rangeland environments: the relative contribution of grazing and climatic variability. Applied Vegetation Science 4:177-188.

Funlendorf, S. D., AND D. M. Engle. 2001. Restoring heterogeneity on rangelands: ecosystem management based on evolutionary grazing patterns. BioScience $51: 625-632$

Fulbright, T. E., AND J. A. Ortega-S. 2006. White-tailed deer habitat: ecology and management on rangelands. College Station, TX, USA: Texas A\&M University Press. $241 \mathrm{p}$.

Fulbright, T. E., J. A. Ortega-S., A. Rasmussen, and E. J. Redeker. 2008. Applying ecological theory to habitat management: the altering effects of climate. In: T. E. Fulbright and D. G. Hewitt [EDS.]. Wildlife science: linking ecological theory and management applications. Boca Raton, FL, USA: CRC Press. p. 241-258.

GonzAlez, C. L., AND J. D. DodD. 1979. Production response of native and introduced grasses to mechanical brush manipulation, seeding, and fertilization. Journal of Range Management 32:305-309.

GouLd, F. W. 1978. Common Texas grasses. College Station, TX, USA, Texas A\&M University Press $267 \mathrm{p}$.

Grace, J. B., M. D. Smith, S. L. Grace, S. L. Collins, and T. J. Stohlgren. 2001 Interactions between fire and invasive plants in temperate grasslands of North America. In:K. E. M. Galley and T. P. Wilson [EDS.]. Proceedings of the Invasive Species Workshop: the role of fire in the control and spread of invasive species; Fire Conference 2000, First National Congress on Fire Ecology, Prevention, and Management; 27 November-1 December 2000; San Diego, CA, USA. Tallahassee, FL, USA: Tall Timber Research Station. p. 40-65.

GUTHERY, F. S. 1986. Beef, brush, and bobwhites: quail management in cattle country. Kingsville, TX, USA: Caesar Kleberg Wildlife Research Institute Press. 186 p.

Hamilton, W. T., AND C. J. Scifres. 1982. Prescribed burning during winter for maintenance of buffelgrass. Journal of Range Management 35:9-12.

Hatch, S. L., AND J. Pluhar. 1993. Texas range plants. College Station, TX, USA: Texas A\&M University Press. $326 \mathrm{p}$.

Hickman, K. R., G. H. Farley, R. Channell, and J. E. Steier. 2006. Effects of old world bluestem (Bothriochloa ischaemum) on food availability and avian community composition within the mixed-grass prairie. Southwestern Naturalist 51: 524-530.

HobBs, R. J., and L. F. Huenneke. 1992. Disturbance, diversity, and invasion: implications for conservation. Conservation Biology 6:324-337.

HoBBS, R. J., AND S. E. HumpHRIES. 1995. An integrated approach to the ecology and management of plant invasions. Conservation Biology 9:761-770.

Ibarra-F., F., M. Martin-R., J. R. Cox, and H. Miranda-Z. 1996. The effect of prescribed burning to control brush species on buffelgrass pastures in Sonora, Mexico. In: P. F. Ffolliott, L. F. DeBano, and M. B. Baker [EDs.]. Effects of fire on Madrean Province ecosystems. Fort Collins, CO, USA: US Department of Agriculture, Forest Service, Rocky Mountain Forest and Range Experiment Station. Gen. Tech. Rep. RM-GTR-289. p. 195-204.

Johnson, M. V. V., AND T. E. FulBright. 2008. Is exotic plant invasion enhanced by a traditional wildlife habitat management technique? Journal of Arid Environments 72:1911-1917.

Lehmann, V. W. 1969. Forgotten legions: sheep in the Rio Grande plain of Texas. El Paso, TX, USA: Texas Western Press. $226 \mathrm{p}$

Littell, R. C., G. A. Milliken, W. W. Stroup, R. D. Wolfinger, and O. Schabenberger. 2006. SAS for Mixed Models. 2nd ed. Cary, NC, USA: SAS Institute. 840 p.

Low, T. 1997. Tropical pasture plants as weeds. Tropical Grasslands 31:337-343.

Martin-R., M. H., J. R. Cox, and F. IbarRa-F. 1995. Climatic effects on buffelgrass productivity in the Sonoran desert. Journal of Range Management 48:60-63. 
Martin-R., M., J. R. Cox, F. Ibarra-F., D. G. Alston, R. E. Banner, and J. C. Malecheck. 1999. Spittlebug and buffelgrass responses to summer fires in Mexico. Journal of Range Management 52:621-625.

Martín-Rivera, M., F. Ibarra-Flores, F. S. Guthery, W. P. Kublesky, Jr., G. CamouLuders, J. Fimbres-Preciado, and D. Johnson-GoRdon. 2001. Habitat improvement for wildlife in north-central Sonora, Mexico. In: E. D. McArthur and J. Daniel [EDS.]. Proceedings: Schrubland Ecosystem Genetics and Biodiversity; 13-15 June 2000; Provo, UT, USA. Ogden, UT, USA: US Department of Agriculture, Forest Service, Rocky Mountain Research Station. Proceedings RMRS-P-21. p. 356-360.

Mayeux, H. S., JR., and W. T. Hamilton. 1983. Response of common goldenweed (Isocoma coronopifolia) and buffelgrass (Cenchrus ciliaris) to fire and soilapplied herbicides. Weed Science 31:355-360.

McLendon, T. 1991. Preliminary description of the vegetation of south Texas exclusive of coastal saline zones. Texas Journal of Science 43:13-32.

Meyer, M. W., R. D. Brown, and M. W. Graham. 1984. Protein and energy content of white-tailed deer diets in the Texas coastal bend. Journal of Wildlife Management 48:527-534.

Milberg, P., and B. B. Lamont. 1995. Fire enhances weed invasion of roadside vegetation in southwestern Australia. Biological Conservation 73:45-49.

Nolte, K. R., T. M. Gabor, M. W. Hehman, M. A. Asleson, T. E. Fulbright, and J. C. Rutledge. 1994. Long-term effects of brush management on vegetation diversity in ephemeral drainages. Journal of Range Management 47:457-459.

NoRwine, J., AND J. KuRUVILLA [EDS.]. 2007. The changing climate of south Texas 1900-2100: problems and prospects, impacts and implications. Kingsville, TX, USA: CREST-RESSACA Texas A\&M University-Kingsville. 158 p.

Peterson, M. J. 2001. Northern bobwhite and scaled quail abundance and hunting regulation: a Texas example. Journal of Wildlife Management 65:828-837.

Reynolds, J. P., T. E. Fulbright, and S. L. Beasom. 1992. Mechanical rejuvenation to dampen seasonal variation in chemical composition of browse. Journal of Range Management 45:589-592.
Ruthven, D. C., III, J. F. Gallagher, and D. R. Synatzske. 2000. Effect of fire and grazing on forbs in the western south Texas plains. Southwestern Naturalist 45:89-94.

Ruthven, D. C., III, and K. L. Krakauer. 2004. Vegetation response of a mesquitemixed brush community to aeration. Journal of Range Management $57: 34-40$.

SAS InSTITUTE. 2008. JMP 8 statistics and graphics guide. Version 8. Cary, NC, USA: SAS Institute. $1218 \mathrm{p}$.

Scifres, C. J., and W. T. Hamilton. 1993. Prescribed burning for brushland management: the south Texas example. College Station, TX, USA: Texas A\&M University Press. $264 \mathrm{p}$.

SCIFRES, C. J., AND D. B. Polk, JR. 1974. Vegetation response following spraying a light infestation of honey mesquite. Journal of Range Management 27:462-465.

Simmons, M. T. 2005. Prairie restoration management plan, Lyndon B. Johnson National Historical Park, Johnson City, Texas. Johnson City, TX, USA: Lady Bird Johnson Wildflower Center. $32 \mathrm{p}$.

Smith, M. D., And A. K. Knapp. 1999. Exotic plant species in a C 4-dominated grassland: invasibility, disturbance, and community structure. Oecologia 120:605-612.

Smith, M. D., and A. K. Knapp. 2001. Size of the local species pool determines invasibility of a C4-dominated grassland. Oikos 92:55-61.

Suding, K. N., And K. L. Gross. 2006. Modifying native and exotic species richness correlations: the influence of fire and seed addition. Ecological Applications 16:1319-1326.

USDA-NRCS. 2010. Natural resources conservation services web soil survey. Available at: http://websoilsurvey.nrcs.usda.gov/app. Accessed 12 January 2010.

Vermeire, L. T., R. B. Mitchell, S. D. Fuhlendorf, and R. L. Gillen. 2004. Patch burning effects on grazing distribution. Journal of Range Management 57:248-252. 